\title{
On the Content of the Pre-service Teachers' Teaching Reflection in the Practicum
}

\author{
Ling Wang \\ School of Foreign Languages, Nanchang Normal University, Nanchang, China
}

\begin{abstract}
Reflection plays an effective role in promoting teachers' professional growth and improving teachers' overall quality. As for Pre-service teachers, teaching practice is an indispensable period for their professional development. Therefore, reflective consciousness and ability should be trained in their practicum. This paper fully elaborates the importance of reflective consciousness for middle school pre-service teachers in the practicum from the contents of the pre-service teachers' teaching reflection: classroom teaching, student study, teacher-student interaction, teachers' development and education environment. From the research, we find pre-service teacher often reflect on classroom teaching, student study and teacher-student interaction. The other two parts are usually neglected.
\end{abstract}

Index Terms - teaching practice, teaching reflection, content of teaching reflection

\section{INTRODUCTION}

Since the 1980s, sprang up from North America, the campaign of reflective teacher teaching has developed rapidly and had profound significance, which has been recognized by most countries in the world and swiftly becomes an international trend. A huge number of teachers' teaching slogans have rose in the global field of teacher teaching, such as reflection, reflective teaching, reflective practice, reflective teacher, and teacher as researcher and so on(Wang Chunguang 2010). There is no doubt that reflection has become a breakthrough on the reform of teacher teaching. Therefore, improving teachers' quality, and promoting teacher's professional development has become a hot point. What's more, apart from having teaching experience, teachers are required to do research as well. Their inner thinking of student, teaching process, social value and teacher professionalization etc. is of great importance. Many researchers realized reflective teacher teaching is an optimal approach to realize teacher professionalization, the best cut-point for teacher's professional development.

Teaching reflection is a critical way to promote teachers' development. By reflecting, teachers can find out the teaching problems, check their teaching behaviors and improve their teaching ability. Accordingly, teachers will have a full understanding of the teaching activity and be apt to the continuous changing needs of education. Teachers' roles alter with the development of the economy and society. It's universally acknowledged that teacher's contribution and dedication made for education and society is tremendous huge in China. Nevertheless, teachers' professional development and growth as well as creativity have been neglected for a long time. With the implementation of the new curriculum, teachers are expected to put on new roles (Wang Qiang 2006). Those who own tremendous experience and rationalized thinking can be regarded as good teachers. Teachers as researchers, who process the ability to carefully observe a problem, consider the reasons, work out probable solutions, then implement the solutions and evaluate the results finally. Since many researches mainly concentrate on the reflection condition of elementary and middle school in-service teachers, there is rarely study that concerns with pre-service teacher. The sooner teachers cultivate their reflective thinking, the better it will be. The practicum is a crucial time to establish the consciousness of reflection. Only through learning to reflect can pre-service teacher continuously correct mistakes and keep exploring to step into a new realm. In this essay, the contents of the pre-service teachers' teaching reflection will be well elaborated. Therefore, researches on the teachers' reflection, transforming the pre-service teachers into reflective teachers are equal to seizing the key point of teacher's professional development, which is of great theoretical and practical significance.

As a crucial mechanism for teacher's self-development, reflection is an important approach to promoting teacher's professional development. Teacher's professional development is a program that one goes through pre-service teacher training phase and in-service phase until he or she leaves the teaching career, during the whole period he or she must continuously keep studying and doing research, develop his or her specialty connotation and gradually march towards the level of professional maturity. As a pre-service teacher, the gaps between expert teachers in all respects are terrifically wide. Nevertheless, many pre-service teachers may ignore the importance of teaching reflection for they mainly pay attention to their live in the practicum. Accordingly, this thesis tries to delve into the content of pre-service teachers' teaching reflection, the methods of their teaching reflection and the affecting factors of their teaching reflection. There are five respects of teaching reflection: classroom teaching, student study, student-teacher interaction, teachers' development and education environment. This essay mainly endeavors to work out whether the pre-service teachers took all these five aspects into consideration, and what factors influence their teaching reflection. In order to obtain the answers, the following three questions are involved: (1) What are the contents of the pre-service teachers' 
teaching reflection in the practicum? (2) What methods are used by the pre-service teachers in teaching reflection in the practicum? (3) What factors influence the pre-service teachers' teaching reflection in the practicum?

A teacher may not be an expert teacher if he writes teaching plan for a lifetime, but if he writes reflection for three years, he could be a famous teacher. Reflective journal is of great importance for pre-service teacher to recall, consider and evaluate the problems happened in profession practicum, and then explore the methods to settle these problems. Reflective journal is usually related with the feeling and viewpoints of teachers' teaching. Therefore, through analyzing the reflective journals of pre-service teachers, the author can deeply comprehend the contents of their reflective teaching. The author collected two reflective journals, which choose randomly from the thirty-one participants. What's more, these reflective journals only applied for this research, which were also written in Chinese. After collecting the reflective journals, the author analyzed their content.

\section{LITERATURE REVIEW}

\section{A. Definition of Teaching Reflection}

In the western countries, as far as most experts and scholars of researching reflection were concerned, John Dewey was considered as the originator who systematically illustrated reflective question. Dewey was also regarded as the first one presented the definition of reflection in his book How We Think. According to Dewey (1910), reflection considers any belief and the knowledge and conclusions involved in the research field. Donald A. Schon (1987) in his book Educating the Reflective Practitioner identified reflection based on technical rationality. He thought that professional practice is an important process of problem solving.

Towards teaching reflection, Jack C. Richards (1996) in his book Reflective Teaching in Second Language Classrooms developed a reflective approach to teaching that involves in pre-service teachers collecting teaching data, checking attitudes and practices, and finally this information will be used in the teaching reflection. Kenneth M. Zeichner \& Daniel P. Liston (1987) regarded a reflective teacher should be one who owns comprehensive ability in assessing the purposes and results of his or her work.

In Chinese, Confucius was regarded as the first one to propose reflection. He told us that learning without thinking is bourbons, thinking without learning is perilous. Chinese scholars gradually realized that the reflection of teaching experience was an appropriate technique to bridge the gap between new teachers and expert teachers, so they started paying attention to reflection and reflective teaching.

Xiong Chuanwu (1999) in his book reflective teaching defined reflective teaching as a process, with the help of action research, that teachers unceasingly explore and tackle the problems related to themselves, teaching goals, teaching tools and so on, combine 'learning how to teach' with 'learning how to learn', endeavor their best to promote teaching practice rationality and make them become expert teachers. Wang Chunguang (2010) described reflection as a process that teachers should regard solving problems in teaching as the aim, take their own teaching process as the thinking object, and examine and analyze the decision, behavior and the results produced in their teaching.

\section{B. Types and Levels of Teaching Reflection}

Based on John Dewey's research, Donald A. Schon (1983) in his book The Reflective Practitioner illustrated two types of reflection, which were reflection-on-action and reflection-in-action.

As for the levels of teaching reflection, a great number of scholars shed light on their perspectives. Linda Valli (1997) concluded five models of reflection and reflective teacher education, which are technical reflection, reflection-in-action, deliberative reflection, personalistic reflection, and critical reflection. Kenneth M. Zeichner and Daniel P. Liston(1996) in the book Reflective Teaching: An Introduction introduced Handal and Lauvas' opinion, who divided teaching practical reflection into three levels: level one is about routine teaching behavior, which could be apparently or easily observed; level two is related with reflection and plan; level three is concerned with reflection on teaching practice from the ethical perspective. According to their opinion, what the most important is to take all aspects of every teaching practical level into consideration. Edward G. Pultorak (1996) chose an approach fashioned after Van Manen's conception of levels of reflectivity, which would be much more useful in classifying teacher reflectivity. Here is Van Manen's (1977) conception of levels of reflectivity: level one is technical rationality. Van Manen identifies this level as the empirical-analytic paradigm, which belongs to the lowest level of reflection; level two is practical action, and he identifies this level as the hermeneutic- phenomenological paradigm; critical reflection is the third level, and Van Manen(1977) labels this level as the critical dialectical paradigm and classifies it as the highest level of reflection.

In China, based on Van Manen's conception of "levels of reflectivity", Shen Jiliang and Liu Jiaxia (2004) divided the level of teaching reflection content into three parts: pre-reflection level, quasi-reflection level, and reflection level.

\section{Contents of Teaching Reflection}

Some researchers hold that teaching reflection is teachers reflect on their teaching skills, techniques, methods and other related aspects, which aims to evaluate the effectiveness of their teaching behavior so that they can change their teaching behavior.(Liu Jiaxia \& Shen Jiliang, 2003)

Chinese scholars and practitioners research contents of teaching reflection from various aspects. Zhang Lichang (2001) divides the content of teaching reflection into two levels: general level and specific level. General level contains 
the reflection of teaching aims and teacher-student relationship. The second level specific level is closed linked with the events happened in the classroom. Besides, he divides the content of teaching reflection into two respects, too. The former puts emphasis on theories, while the later concentrates on practice. Zheng Jinzhou(2000) proposes the content of teaching reflection not only includes the discussion of classroom teaching, but maybe consider the content of cases, as well as the participation of yourself and the other group's members. The critical teaching reflection is divided into four parts, which are system of belief, system of knowledge, teaching practice and background.

Liu Xudong and Meng Chunguo (2010) thought the contents of teaching reflection should include five respects: teaching, student, teacher, teacher-student interaction, and education environment. Teaching reflection should also include five respects: teaching, students, teachers, classroom management, and education environment. As far as she is concerned, many student English teachers often reflect on teaching, students and teachers, while the latter two aspects are frequently ignored.

All these researchers above conclude the content of teaching reflection from different aspects, and almost all involve three factors: teacher, student and teaching, which enrich the study of teaching reflection.

Although great progress has been made in above fields, the gaps both in quantity and quality are still deadly large. There are some existing papers referring to the historical development, background and significance of the implementation of the reflective teaching; introduction and evaluation of the reflective thought elaborated by the scholars represented by Schon and Dewey, but they are just simply analyzing it from the single aspect of teaching reflection. Researchers seldom discussed the content of teaching reflection with respect to teaching combining with our country's educational teaching practice, especially the currently new situation of curriculum reform in primary and middle schools. Though the domestic researchers did a lot in the work of summarizing and concluding, they lack of the original creativity, systemic and empirical research.

\section{RESUlTS OF THE RESEARCH}

\section{The Contents of Pre-service Teachers' Teaching Reflection}

The author divides the content of pre-service teachers' teaching reflection into five respects: teaching reflection,It consist of classroom teaching, student study, teacher-student interaction, teachers' development and education environment. The questionnaire mainly investigates the opinions of pre-service teachers on what contents should be included in their teaching reflection, and whether pre-service teachers take the five aspects into consideration, which part they usually highlight and which part they often ignore.

Question one is about what aspects should be consisted in the teaching reflection. From the research we can find out a great number of participants maintain all the five parts, They think classroom teaching, student study, student-teacher interaction, teacher development, and education environment, are the contents of teaching reflection. All the participants believe that classroom teaching, which consists of classroom organization, classroom activities, teaching material, teaching goals and so on, is an indispensable part of their teaching reflection. No more than seven percent student English teachers ignore student study and student-teacher interaction, as well as less than thirteen percent pre-service teachers disregard teacher development. What's more, there are almost twenty percent pre-service teachers treating education environment as an unimportant aspect, so there is no need to reflect on it.

Question two is about what respects are involved in their own teaching reflection in reality. The results demonstrate that approximately all pre-service teacher reflect on classroom teaching (such as classroom organization, classroom activities, teaching material, teaching goals and so on), student study (such as behavior and attitude of student study, the use of learning methods and strategies, and academic record) and teacher- student interaction (such as cooperation and conflict between teacher and student as well as teacher-student relationship in and out of the class). Around seventy seven percent pre-service English teachers can reflect on teacher development, which is closely connected with teacher professional development, but few pre-service teachers put emphasis on education environment. We can clearly find out that these two parts are more straightforwardly overlooked aspects in the process of reflection.

Question three is the ranking of the content of teachers' reflection in terms of importance. Undoubtedly, classroom teaching is the most important part according to most of the pre-service teachers. Student study lies in the second place. Next one is about teacher-student interaction. Teacher development ranks forth and the least important part is education environment (such as reform of education system, social background and parents support, and school atmosphere).

In conclusion, according to the research results from the questionnaire, it was not hard to find out that almost all the pre-service English teachers believe that teaching reflection should comprise all the five aspects: classroom teaching, student study, teacher-student interaction, teacher development and education environment. Nonetheless, in reality, the principal contents of their reflections are related to classroom teaching, student study and teachers themselves, the other two parts teacher-student interaction and education background are always ignored. Teaching reflection is not only the simple description of events, but also tries to explain and offer evidence for the teaching events and behaviors. Education is a complicated task and contains a great number of things. Novice teachers may as well take all the things associated with their teaching into consideration. Therefore, in their future teaching career, they would pay attention to teacher-student interaction and education environment too.

By analyzing the two pre-service English teachers' reflective journals, the author endeavors to confirm the contents of their teaching reflection. 
In teacher X's reflective journal, she said, she was a little afraid to teach the two nine grades for following reasons: on the one hand, the two classes were famous for bad habits, poor grades and poor discipline, which were labeled as parallel classes; on the other hand, teacher $X$ was not familiar with those students, teaching material and teaching methods, even worse, she hadn't made any preparation for the teaching. When she checked the answer and explained the reasons completely, there still a few minutes left, but the class discipline was terrible and even out of control. Then she stopped some students talking in the class, then introduced herself and had a basic understanding of the students. She followed the rules established by the former English teacher, as well as added several more democratic class regulations in order to get the trust and support of students.

Analyzing from teacher X's reflective journal, we can find out that she mainly reflects on three aspects: classroom teaching, student study and teacher-student interaction. She realizes the problems of students, which may lead to the hard process of teaching, so she reflects on student behavior and attitude, and classroom management and organization as well as teaching material. In addition, she not only tries her best to understand students' feelings and bad behaviors, but also sets several more democratic classroom rules to win the cooperation of students, which belong to the teacher-student interaction. Only in this way can she establish a sound relationship with students and gain the trust and support of students. Above are the principal parts that she reflects. The other two aspects teacher development and education environment can't be found in her reflective journal.

In teacher Y's reflective journal, she said, it was the first time that she had formally stepped to the platform, and she was a little nervous. Students of grade seven had various discrepancies in learning foundations. For example, those who transferred from country elementary school rarely owned the opportunity to have a basic knowledge of English. Besides, there was a student transferred from the Xinjiang Uygur Autonomous Region, where his learning content was totally different from ours, and he hadn't learnt any English in school. Therefore, the learning material in the starter unit one to three was of vital importance for those students who had poor basis. What's more, there were more than seventy students in the class from different primary schools, they haven't formed class consciousness, so teacher $Y$ needed to guide them behave well and help them alter the bad habits, such as talking in low voice when teacher was teaching learning material. Lastly, pronunciation rules play an essential role in English learning, so she continuously corrected the wrong pronunciation of students and encouraged them to speak confidently.

As we can see, teacher Y mainly reflects on two aspects: classroom teaching, student study. She has taken students' basic information of English learning into account and paid attention to their discrepancies in order to teach students in accordance with their aptitude. This part is involved in student study and classroom teaching. What's more, she also helps and instructs students to form good habits, which also belongs to student study. The other three parts teacher-student interaction, teacher development and education environment are not mentioned in her reflective journal.

Through analyzing the two student English teachers' reflective journals, it is easy for us to draw a conclusion that they often reflect on classroom teaching and student study. The other three parts teacher-student interaction, teacher development and education environment may be ignored by them. Reflection is not a purpose, but a means. It is of no meaning if reflection cannot solve the practical problems. Hence, student English teachers need to process reflection consciousness and put it into practice to settle the puzzlement and problems encountered in teaching practice.

\section{CONCLUSION}

On the basis of previous study and discussion, the author tries her best to make use of questionnaire and reflective journals to find out the content of the pre-service English teachers' teaching reflection,. According to the results from the questionnaire and reflective journals, the main findings are shown as following:

As for the content of the pre-service English teachers' teaching reflection, there are five aspects are mainly included in it. They are classroom teaching, student study, teacher-student interaction, teachers' development and education environment. Classroom teaching includes classroom organization, classroom activities, teaching material, teaching goals and teaching methods and so on. Student study contains behavior and attitude of student study, the use of learning methods and strategies, and academic record of students. Student-teacher interaction is about cooperation between teacher and students, conflicts between teacher and student and its treatment, as well as teacher-student relationship in and out of the class. Teacher development is related with teachers' self-development consciousness, teachers' conceptions and teaching behaviors, planning for professional development, as well as identity. Education environment consists of reform of education system, including the new elementary education curriculum reform, social background and parents' support, and school atmosphere of teaching reflection. Most teachers have a belief that all the five parts classroom teaching, student study, teacher-student interaction, teacher development and education environment should be included in the reflection. However, they often reflect on classroom teaching, student study and teacher-student interaction. The other two parts are usually neglected. Almost all the teachers hardly reflect on education environment.

\section{REFERENCES}

[1] Dewey, J. (1910). How We Think . Boston, U.S.A: D. C. HEATH \& CO.

[2] Edward G. Pultorak. (1996). Follow the Development Process of Reflection in Novice Teachers: Three Years of Investigation. Journal of Teacher Education, 4,284-321.

[3] Kenneth M. Zeichner \& Daniel P.Liston. (1996). Reflective Teaching: An Introduction. Mahwah, New Jersey: Lawrence 
Erlbaum Associates Inc,

[4] Kenneth M. Zeichner \& Daniel P. Liston. (1987). Teaching Student Teachers to Reflect. Harvard educational review, 1, $23-48$.

[5] Liu Xudong \& Meng Chunguo. (2010). On the Content of English Teaching Reflection and the Development of Reflective Level. Foreign Language Teaching in Schools.12, 2-16.

[6] Richards, Jack C. \& Charles Lockhart. (1996). Reflective Teaching in Second Language Classrooms. Cambridge: Cambridge University Press.

[7] Schon, D A. (1987). Educating the Reflective Practitioner. New York: Jossey-Bass Publishers.

[8] Schon, D A. (1983). The Reflective Practitioner: How Professionals Think in Action. New York: Basic Books.

[9] Shen Jiliang \&Liu Jiaxia. (2003). Review of Overseas Studies of Reflective Pedagogical Thinking. Review Comparative Education. 10, 33-36.

[10] Shen Jiliang \&Liu Jiaxia. (2004). A study of Teachers' Teaching Reflection. Journal of East China Normal University (Educational Sciences). 3, 44-46.

[11] Valli, L. (1997). Listening to other voices: A description of teacher reflection in the United States. Peabody Journal of Education, 72 (1), 67-88.

[12] Van Manen. (1977). Linking Ways of Knowing with Ways of Being Practical. Curriculum Inquiry, 3, $205-228$.

[13] Wang Qiang. (2006). A Course in English Language Teaching. Beijing: Higher Education Press,

[14] Wu Zhaoliang. (2011). A Study of Teaching Reflection in the Practicum. Global Education. 6,53-55.

[15] WangChungGuang. (2010). A Study of Reflective Teacher Education. ChangChung: Beidong Normal University Press.

[16] Xiong Chuanwu. (1999). Reflective Teaching. Changchun: ShangHai: Huadong Normal University Press.

[17] Zhang Lichang. (2001). Review of Teacher Reflection and Strategies. Educational Research.12, 18-20.

[18] Zheng JinZhou. (2000). Guide of Case Teaching. ShangHai: Huadong Normal University Press.

Ling Wang was born in Jian, China in1967. She received her bachelor of Art degree in linguistics from Jiangxi Normal University, China in 1995.

She is currently an associate professor in the School of Foreign Languages, Nanchang Normal University, Nanchang, China. Her research interests include cross-cultural teaching and teaching methods.

Prof. Wang is a member of the Chinese Association of Foreign Language Teacher. 